\title{
TEACHING ENGLISH FOR YOUNG LEARNERS USING A DIGITAL COMIC STRIP
}

\author{
I Ketut Trika Adi Ana \\ STKIP Agama Hindu Singaraja, Jl. Pulau Timor No. 24 Singaraja \\ e-mail: adiana_adi@yahoo.co.id
}

\begin{abstract}
Teaching English for Young Learners Using a Digital Comic Strip. Since young learners get bored easily, English teachers should be creative in designing the instruction in order to make it interesting for the students. One of the ways that can be done by the English teachers to make their teaching and learning process becomes an interesting activity is by providing good teaching media. It is believed that young learners love story and colorful teaching media. Therefore, this article aims at explaining how to create a colorful digital comic strip and how to use it for teaching English. Specifically, this article discusses about: (1) the role of story in teaching English for young learners; (2) how to design and develop a digital comic strip; (3) how to teach English for young learners using a digital comic strip; and (4) the benefits of teaching English for young learners using a digital comic strip. It is expected that this article could give enough information for those English teachers who want to teach English for young learners using a digital comic strip.
\end{abstract}

Keywords: comic strip, instructional media, young learners

\begin{abstract}
Abstrak: Pembelajaran Bahasa Inggris untuk Peserta Didik Anak-Anak Menggunakan Komik Strip. Para guru yang mengajar Bahasa Inggris untuk anak-anak hendaknya kreatif dalam mendesain sebuah pembelajaran untuk menciptakan pembelajaran yang menarik bagi peserta didik. Hal tersebut karena peserta didik anak-anak sangat cepat bosan. Salah satu cara yang dapat dilakukan untuk mencipatakan pembelajaran yang menarik adalah dengan membuat media pembelajaran yang bagus. Anak-anak biasanya menyukai cerita dan media pembelajaran yang berwarna-warni. Untuk itu artikel ini akan menjelaskan mengenai cara mengembangkan komik strip digital berwarna dan strategi untuk mengajar Bahasa Inggris menggunakan komik strip digital tersebut. Secara spesifik, artikel ini akan membahas mengenai: (1) peranan cerita dalam pembelajaran Bahasa Inggris untuk peserta didik anak-anak; (2) cara mendesain dan mengembangkan komik strip digital; (3) strategi mengajar menggunakan komik strip digital; dan (4) manfaat pembelajaran bahasa Inggris menggunakan komik strip digital. Diharapkan artikel ini dapat memberikan informasi yang cukup bagi guru yang tertarik untuk mengajar Bahasa Inggris menggunakan komik strip digital.
\end{abstract}

Kata-kata Kunci: komik strip, media pembelajaran, peserta didik kanak-anak,

Teaching English for young learners is not the same as teaching English for adult learners. It is because young learners have different characteristics compared to adult learners. Some experts have identified important characteristics of young learners that should be considered during the instruction process. Brown (2001), identified that young learners have a very short span of concentration. He stated that young learners cannot concentrate for more than fifteen minutes. Similar opinion is also given by Cameron (2005), who stated that young learners will get bored easily during the teaching and learning process.

When young learners think that the instruction is not interesting, they will start to focus on something else. Sometimes, they will start to talk to themselves and do not pay attention to their teacher. That condition happens because young learners are very imaginative (Halliwell, 1993).They have the ability to visualize their imagination and that is the reason why young learners love to hear story. In addition, for young learners, seeing, touching, 
and listening are as important as teacher's explanation and they love to play game very much (Harmer, 2007).Thus, in order to make young learners able to concentrate and enjoy the instruction, English teachers should provide interesting activities that give some chances for the learners to interact. Making young learners enjoy the instruction is very important, because they will learn better when they feel happy and fun (Scott \& Y treberg, 2000).

From the explanation about young learners' characteristics above, it can be understood that it is very important to provide young learners with an interesting teaching and learning activities. Teaching English for young learners by telling a story using a colorful comic strip can be an interesting activity for young learners. However, to find a comic strip that is appropriate with the learning objective is not an easy job. The best way to get an appropriate comic strip is by creating it individually. Yet, the problem is that not all of the English teachers have the ability to draw pictures. Therefore, this article provides some information about how to create a digital comic strip for teachers who did not have the ability to draw good pictures using the application in bitstips.com and some ideas in teaching English for young learners using adigital comic strip.

\section{DISCUSSION}

\section{The role of Story in Teaching English for Young Learners}

Stories have been used by English teachers for teaching English for years. It is because teaching English through stories is believed to bring some benefits to improve the effectiveness of the instruction. In teaching English as a foreign language for young learners, the use of a story helps the learners to learn English better, since the story provides the learners with real world expereincesand relationship among the native speakers of English or thetarget language culture (Littlewood, 2001; Saka, 2014). In addition, teaching through stories is entertaining for young learners and it helps them to understand the world (Barton \& Baguley, 2014). Similar opinion also comes from Violetta-Irene (2015), who believed that a story will make teaching and learning process become a lively and motivating activity.
Furthemore, Violetta-Irene also explained that there are three major reasons why teaching English through stories is worth to be done. Those reasons are cultural model, language model, and personal growth model. Through stories, a language learner may learn about the history of the native speakers of the target language. Even, they may also learn about life styles, belief, society, politics of the target language speakers through stories. In other words, stories provide learners with target language cultue and it is very important to understand the target language culture in order to avoid misunderstanding or cultural conflict. Knowing other cultures will make the students be able to accept differences and be tolerant (Choudhury, 2014).

By using a story, the English teachers will be able to give samples of the use of the target language in context. It is important to give sample of the target language use in context in order to train the language learners get the meaning of the language based on its context. It is because sometimes the meaning of an utterance is not the same as the meaning of the words which build the utterance. Therefore, providing samples of language in context will train the learners to use the target language in the real life activities. In addition, since reading a story is entertaining, when the learners could feel it they will read more and more. Those reading activities will develop their Englishmastery.

The English teachers may use story to teach various language skills (Mixon \& Temu, 2006; Pardede, 2011). In order to teach speaking skill, the teachers may ask the learners to do a story telling. Mixon \& Temu suggested that in doing the storytelling activity the English teachers should provide the students with objects or pictures. The function of those objects and pictures is to help the students in delivering the story. To teach listening skill, they suggested the English teachers to read or tell simple stories to the learners. They may also use objects or pictures in reading or telling the stories. For reading activity, the English teachers should select a story that suits the learners' English language mastery. The teachers may start the reading activity by reading aloud activity, in which they give the example of how to read the story first. For writing activity, the English teachers may ask the students to draw pictures or simply provide the pictures that will be used by the students as guidance in writing a story. 
Empirically, some studies confirmed that the use of story is effective in teaching English as a foreign language. Pourkalhor \& Kohan (2013) found that the use of short stories was effective for teaching reading comprehension for the tenth grade students in Iran. Another study that was conducted by Handayani (2013) also found that short stories were proved could enhance students' reading comprehension. In speaking ability, Abdolmanafi-Rokni \& Qarajeh (2014) found that digital storytelling could improve students' mastery in speaking English in Iran. An experimental study that was conducted by Karabacak \& Erdem (2015)also shows that the use of story book increased the success of the learners in mastering English as a foreign language.

From the explanation above, it can be understood that story has an important role in teaching English as a foreign language. It is because it has the ability to make teaching and learning activity becomes a fun activity and at the same time it promotes the target language culture that can develop learners' cross cultural understanding. In addition, stories can be used for teaching the four language skills and even some studies have proventhat the implementation of stories in teaching English is effective in developing learners' mastery on target language.

\section{Designing and Developing a Digital Comic Strip}

Before discussing further on designing and developing comic strip, it is better to understand what a comic strip is. According to Liu (2004: 229), comic strip can be defined as "a series of pictures inside boxes that tell a story". It means that to develop a comic strip we need a story and some pictures. The core problem in developing a comic strip normally lies on the lack of the teachers' ability in drawing pictures. However, the development of technology makes that barrier seems disappear. It is because, nowadays, English teachers who do not have the ability to draw a good picture could create good quality pictures to be used in developing a comic strip by using certain applications. One of the ways that the English teacher can do in producing good pictures for creating comic strip is by using a comic strip application that is provided by bitstrips. com. Using the application, the English teachers do not need to be afraid of their drawing ability, because various pictures can be easily selected and modified based on the teachers' need.

Since the comic is developed using software that already provides some pictures, the English teachers have to identify the available menus to modify the pictures in order to frame their ideas so that the available pictures could represents those ideas. This identification can be done by going directly to the website of bitstrips.com. It is suggested that the English teachers directly go to https://www.bitstrips.com/ create/ comic/, because if they go to the main page, they will find an application to create avatar not the application to create comic strip. The appearance of the web page o create a comic strip can be seen in Figure 1 below. 


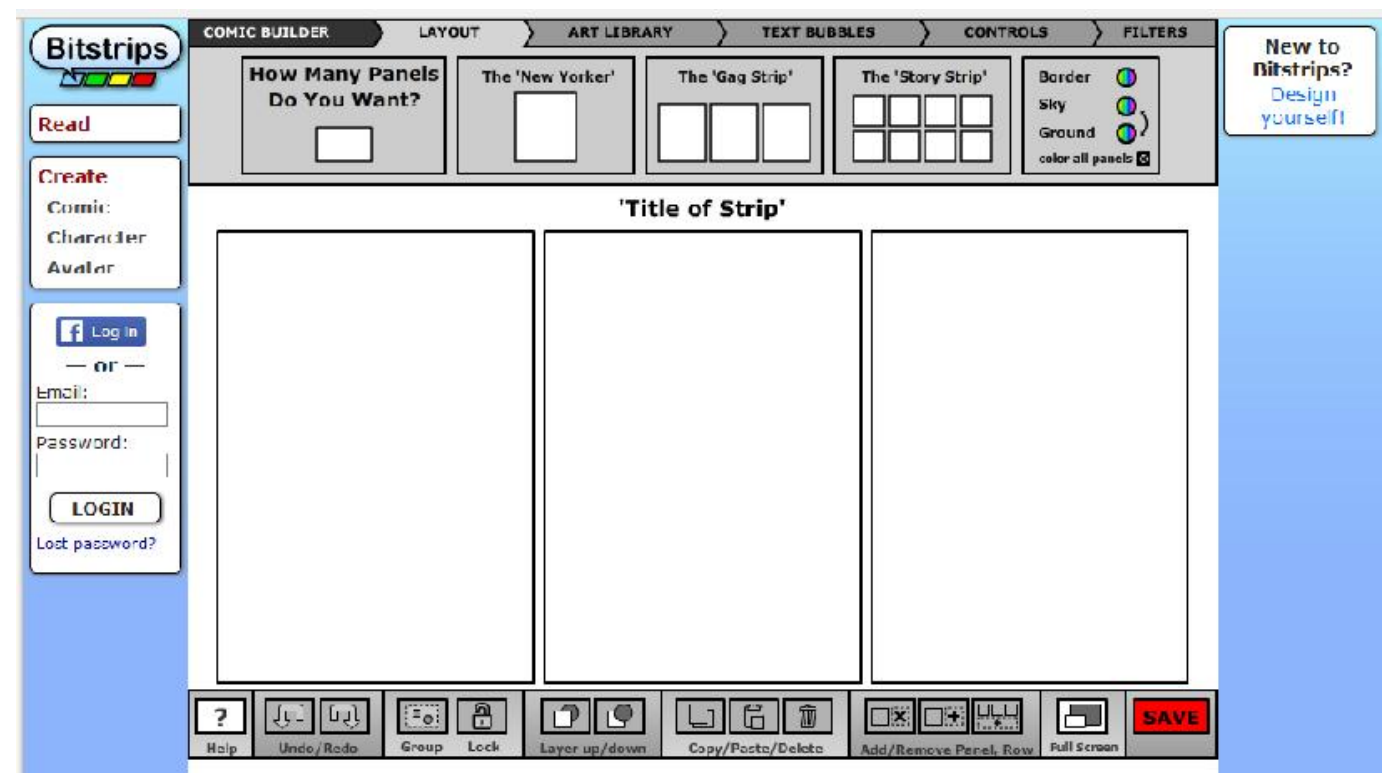

Figure 1. The Web Page of bitstips.com for Creating Comic Strip

When the English teachers have found this webpage, they have to check the available pictures in art library menu, text bubbles, and controls. In art library menu, there are seven sub menus are available, namely: characters, scenes, properties, furnitures, effects, and shapes and outfitssub menus (see Figure 1). From those seven sub menus, three of them are crucial in developing comic strips. Those sub menus are characters, scenes and outfits sub menus. In characters sub menus, there are various characters available, such asbitstrips basic, famous and featured, pet, and my character. Bitstrip basic provides instants characters that the English teachers could select for the comic. Famous and featured provides instant famous and featured characters, e.g. Barack Obama, Bill Gates, George Bush, and Fidel Castro. Pet provides two dogs characters. While my character is a special character that can be made by the English teachers to be inculded in the option.

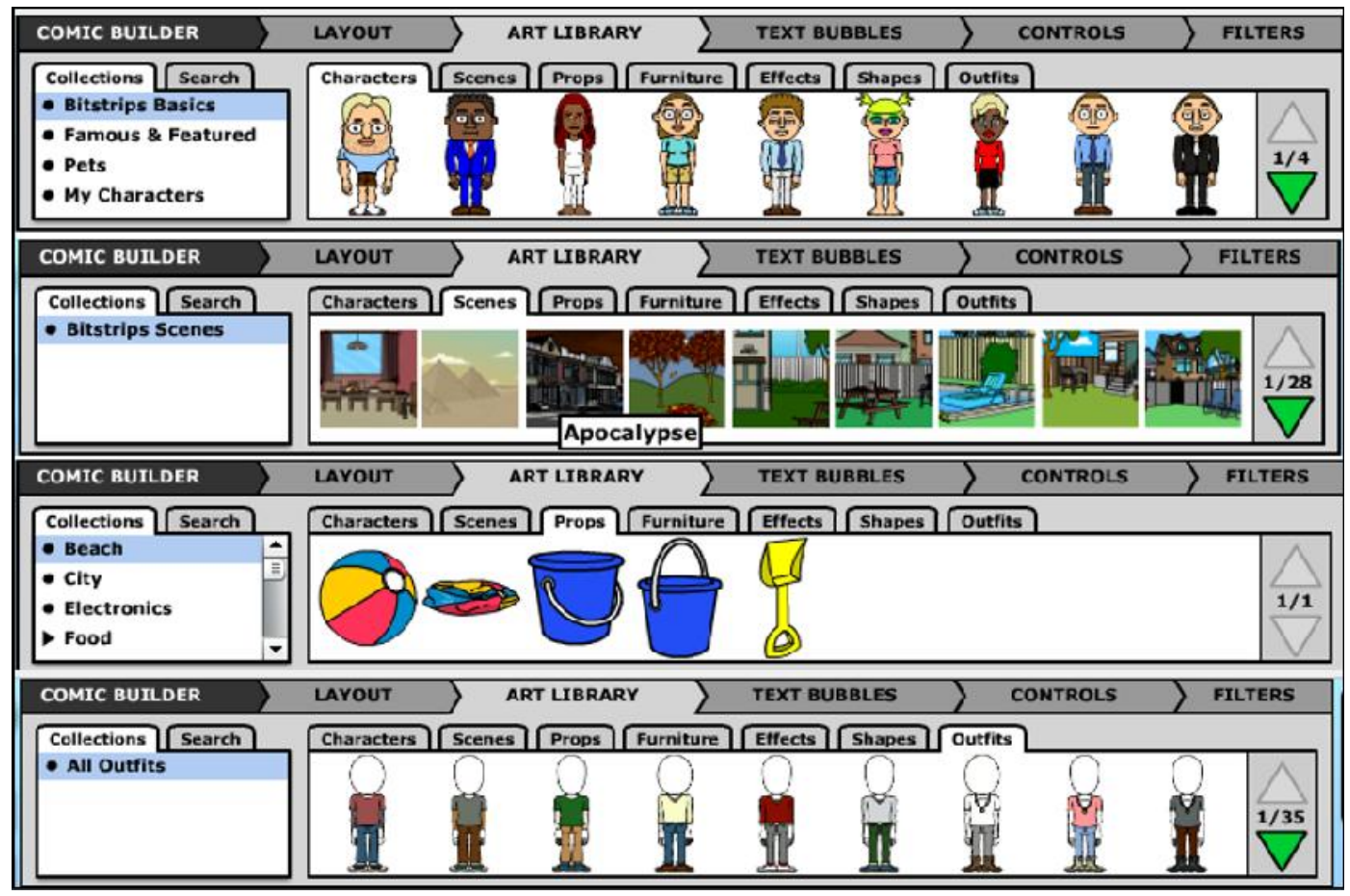

Figure 2. The Art Library Menu in bitstrips.com

In scenes sub menu, some instant scenes are available such as dinning room, backyard, li- brary, bathroom, and beach. This scenes are very useful in order to make the comic strip becomes 
more colorful and contextual. By providing appropriate scene, the students will be able to get the gist of the story. Outfits are also important to create context, it is because outfits should be appropriate with the setting or the context. In bitsrips.com, the outfits sub menus provides various outfits that can be used to change the outfits of the characters. It will ease the English teachers to choose appropriate outfits for the characters in the comic strips. While, the properties, furniture, and effects sub menus only provides few properties pictures, limited effect pictures, and limited shapes pictures that can be used to modify the comic strip.

Text bubble is the menu that provides some text bubbles that can be used to create text bubble for each character that available in the comic strip. Various text bubbles are available for spesific text with special emotions or purposes, for example text bubble for regular speech, whisper, thought, and shout. The availability of the text bubbles will help the English teachers to emphasis the emotion of the characters. The text bubble menu can be seen in Figure 3.

The last menu that should be explored by the English teachers is Control menu. The function of the control menu is to create the emotion and pose of the characters. The emotion of the character can be created by changing the facial expression by choosing the shape of the eyes, lips. While to change the pose of the character can be done by selecting one of the pose that is available in controls menu.

In order to develop a good comic strip that is appropriate with the objective of the instruction, there are some steps that the English Teachers need to follow. The steps that the English teacher need to do in making a comic strip are finding an idea, designing the comic strip, developing the comic strip, and evaluating it. Those steps are explained below.

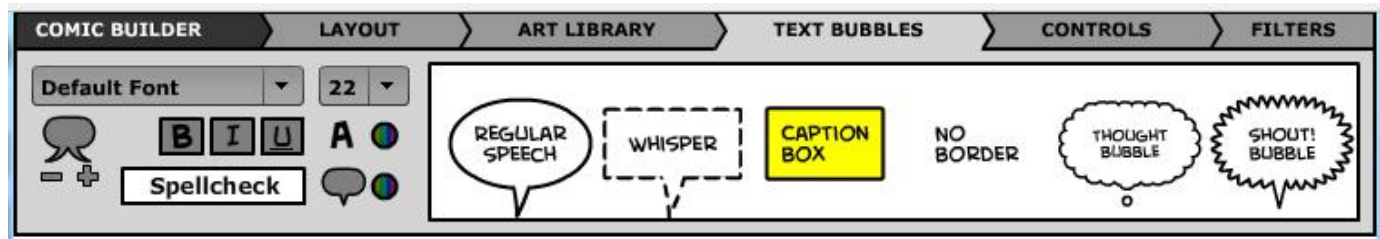

Figure 3. Text Bubble Menu in bitstrips.com

\section{a. Finding Ideas}

Fairrington (2009) explained that ideas for a comic can be found everywhere. The things that should be done to get an idea is by openning our eyes and look arround us. He gives some sources of ideas in producing a comic. Those sources, such as newspaper, magazine, tv news, things kids do, things animal do, funny conversations, funny personal experiences, and fascinating people.Since the comic strip will be used for teaching English, the idea should be in line with the learning objective and the theme which were stated in the syllabus. Sometimes, an idea just comes up instantly and when we do not write it or record it, we will lose it. That is why it is suggested that the English teachers to bring a notebook or a laptop everywhere they go if they do not want to lose their idea.

\section{b. Designing the Comic Strip}

Since the pictures will not be drawn manually, the design of the comic will be made in the form of a blue print. The English teachers may make the design or the blue print of the story by writing it in a notebook or type it in a laptop. As what is suggeted by Ellis \& Brewster (2014), in order to use a story for teaching English there are some important things to be ensured, namely: level of vocabulary structures of fuction, literary devices, content/subject matter, illustration/layouts, educational potential, motivation, global issues, values, and language authentic appropriateness. Considering those aspects, the English teachers should think about all of those aspects in designing the blue print of the comic. In addition, humor is the characteristic of a comic strip (Fairrington, 2009). Thus, the English teachers also need to add humor in their comic. 


\begin{tabular}{|c|c|c|c|c|}
\hline \multicolumn{5}{|c|}{ BLUE PRINT OF THE COMIC STRIP } \\
\hline \multicolumn{5}{|c|}{$\begin{array}{l}\text { Theme: } \\
\text { Title: } \\
\text { Learning objective: }\end{array}$} \\
\hline $\begin{array}{l}\text { Panel } \\
\text { No. }\end{array}$ & Character(s) & Situation/Scene & Language Function & Language Expressions \\
\hline 1. & & & & \\
\hline 2. & & & & \\
\hline 3. & & & & \\
\hline 4. & & & & \\
\hline
\end{tabular}

Figure 4. Sample of Blue Print Format

\section{c. Developing the Comic Strip}

When the blue print has been created, the next step is developing the comic strip by following the blue print. In developing step, the English teacher needs to visualize the idea using the application that is provided by bitstrips.com. The English teachers need to make the details of the story. The English teachers have to make the conversations between/among the characters based on the theme that has been decided. Those conversations should fulfill the aspect of good story for teaching English as what was proposed by Ellis \& Brewster (2014). The steps of developing the comic strip using the application in bitstrips.com can be done by following some steps, namely: deciding the number of the panel,deciding the appropriate scene for every panel, arranging the characters in every panel, and arranging the text bubbles and writing the conversation in every panel. All of those steps are done by consulting the blue print that have been made previously. When all of those steps are done, the comic is ready to be saved. When the co-mic strip is saved, that comic strip will be saved in the form of .jpg file.

\section{d. Evaluating the Comic Strip}

When the comic is ready, before it is implemented in the real teaching and learning process, it will be better to be tried out first. This try out aims at finding out whether or not there are problems in implementing the comic strip during the teaching and learning process. This evaluation can be categorized into formative evaluation. According to Dick \& Carey (2005), the easiest way to do the formative evaluation is by conducting one-to-one trials. In this kind of formative evaluation method only three to five students are involved. Those students are the representatives of the fast learners, moderate learners, and slow learners. To evaluate the comic strip, those three or five students should be taught using the comic strip. While implementing the comic strip to teach those students, the
English teachers should observe the students and the instruction process in order to identify the problems. In addition, the English teacher also may interview the students after the implementation of comic strip. By doing those activities, The English teacher may identify the problems and do some revisions based on the problems found.

\section{Teaching English for Young Learners Using a Digital Comic Strip}

In order to create an effective teaching and learning process by using a digital comic strip, the English teachers may draw their idea in the form of a thematic web. According to Enright \& McCloskey (1998), in teaching English there are some aspects that need to be considered. Those aspects can be seen on the thematic web as seen in Figure 4. The English teacher may develop a thematic web as a guidance in creating a series of appropriate activities expressing the chosen theme, by stating a) interaction, which focuses on oral interaction; b) cultural aspect, which focuses on cultural aspect that will be promoted in the instruction; c) listening activity, which focuses on listening skill, d) reading activity, which focuses on reading skill, e) speaking activity, which focuses on speaking skill, f) writing activity, which focuses on writing skill; g) grammar focused activity, which focuses on indirect aspect of English structure, h) vocabulary activity, which focuses on the use of new vocabulary; and i) experiential activity, which centers around out-of-class activity.

Teaching English through a digital comic strip is similar to teaching English using a pictured story. In teaching listening skill, the English teacher may delete the text that is available in the text bubble and crop each panel using adobe photo shop software. Then, the English teacher may paste it in power point slide show and add text box on the text bubble and then save it in the form of power point slide show 
.pptx. Then the English teacher may create the audio by converting the conversation text using text to speech application that is available in the internet. During the teaching and learning process the English teachers may play the audio and ask the students to fill the text bubble based on the conversation that they heard. This fill in the blank activity using comic strip has been proven by Graham (2011) to be effective in teaching listening.

To teach writing and speaking using the digital comic strip can be done by providing a similar comic strip as what is used in listening task, that is a comic strip without any text. The English teachers should make the comic strip in the form of slide show. The English teachers play the slide show for several times. While looking at the slide show, the students should write a story based on the slide show. Then, the English teachers may ask the students to tell the story orally without reading the story that they have written. Teaching writing and speaking through comic strip is worth to be done, because some researchers have found that the use of comic strip as teaching media could improve students' writing skill and speaking skill (see Graham, 2011; Megawati \& Anugerahwati, 2012; Rokhayani, 2014).

In teaching reading, the English teacher make use comic strip that is not arranged in a correct order. The English teacher may make the digital comic strip in the form of slide show. However, the arrangement of the panels should be randomized. The students have to arrange the panels into their correct order. In order to do that, the students have to read the conversation. Then they have to move the panels based on their understanding toward the conversation of each panel that they have read. Some studies have been conducted to find out the effect of the implementation of comic for teaching reading to learners of English as a foreign language and the result of those studies show that the use of comic has a significant effect toward the learners' reading comprehension (see Liu, 2004; Kobayashi, 2011; \& Merc, 2014).

From those explanations above, it is obvious that digital comic strip can be used for teaching four language skills. Furthermore, some studies also confirmed that the implementation of comic strip is effective to enhance learners' English language skills. Those facts make the use comic strip is recommended for teaching English for young learners. In addition, all of the teaching activities above can be followed by other activities that emphasize on the vocabulary, English grammar, and cultural aspect. They can be in the form of paper and pencil test or performance assessment. They are very important in developing the mastery of the learners in the target language.

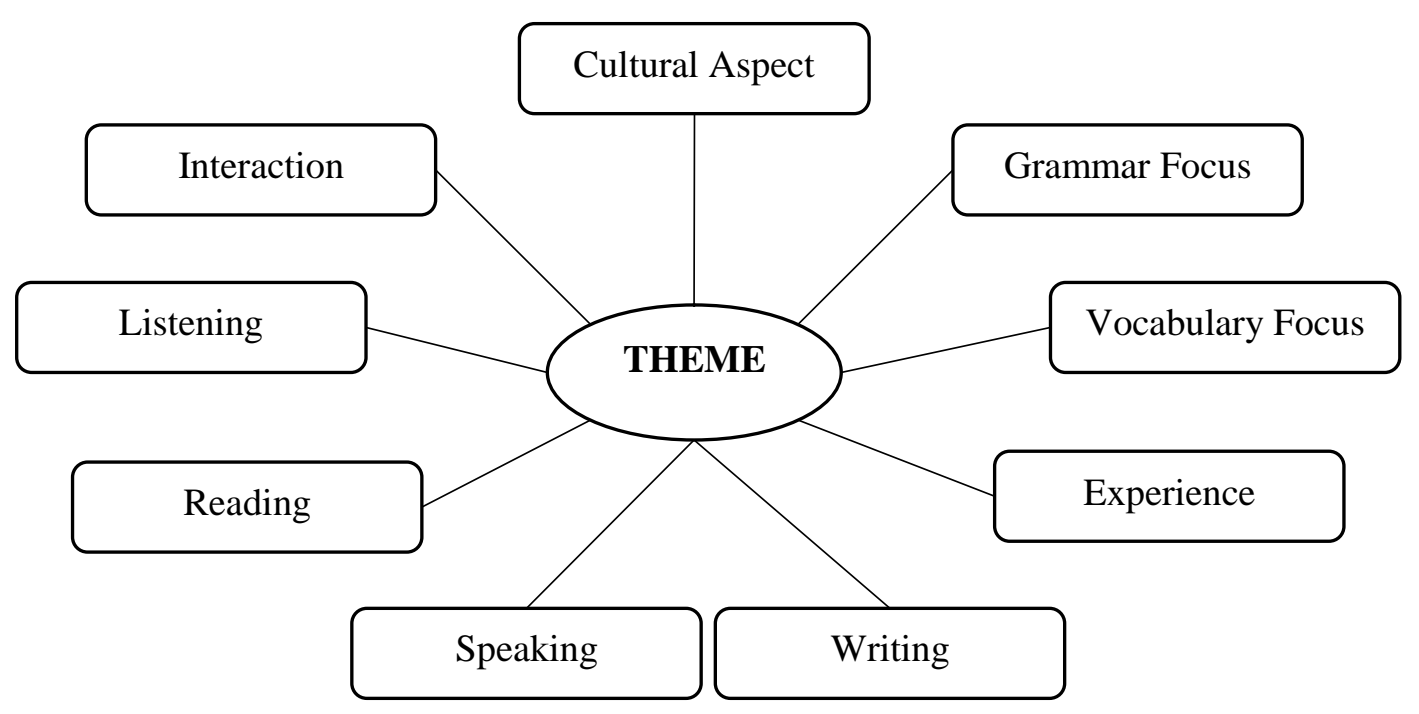

Figure 5. Thematic Web to Help the English Teachers in Designing an Instruction

\section{Benefits of Teaching English for Young Learners Using a Digital Comic Strip}

There are some benefits that can be achieved by teaching English for young learners using a digital comic strip. Those benefits are: 
a. Teaching English through Digital Comic Strip is Fun

As what has been explained previously, in teaching English for young learners, the English teachers should be able to make the teaching and learning process becomes an interesting activity. According to Cs a bay (2006), comics have similar effect as educational game, since comics bring a cheerful atmosphere into the class. That opinion is supported by Rokhayani \& Utari (2014) who found that colorful comics could make young learners becomes interested to join the teaching and learning activity. In addition, it is also found that young learners enjoy reading comics, so it makes perfect sense to use such a resource to enhance English language learning (Graham, 2011).

b. Digital Comic Strip is Effective for Teaching English for Young Learners

Comic strip is effective to enhance young learners' English mastery. It has been proven by Merc (2014) comic strip has significant effect on students' reading comprehension. Another study that was conducted by Kobayashi (2011) which used comic strip as a visual aids found that the use of comic strip reduced the learners' cognitive load in reading and promoted the retention of the text in retelling task. In addition, Megawati \& Anugerahwati (2012) also found that teaching writing using comic strips could successfully improve students' ability in writing (Megawati \& Anugerahwati, 2012). From the results of those studies it can be concluded that digital comic strip is effective for teaching English for Young learners. Furthermore, the use of digital comic strip also can promote cross cultural understandding.

c. Digital Comic is Economical

Since digital comic is produced in the form of digital pictures and slide show, it means that it is very easy to be duplicated. It is different from

\section{REFERENCES}

Abdolmanafi-Rokni, S. J., \& Qarajeh, M. 2014. Digital storytelling in EFL classrooms: The effect on Oral Performance. International Journal of Language and Linguistics, 252-257.

Barton, G., \& Baguley, M. 2014. Learning through story: A collaborative, multimodal the paper based comic that in order to produce it needs relatively a lot of money. In addition, since the comic is in digital form, it is very easy to be modified for different teaching purposes. This modification is also done digitally on the computer, so the cost to do the modification and to pro-duce the comic strip is low. As what is explained by Gunduz (2005) that a computer assisted language learning is inexpensive, because the product can be easily copied and shared. Similar opinion also comes from Miangah \& Nezarat (2012) that teaching media which are developed and shared through information and communication technology will be low in cost that need to be spent.

\section{CONCLUSION}

The English teachers who teach English for young learners should be creative in designing their instruction. Since young learners cannot concentrate for a long time and are easy to get bored. Therefore, an interesting teaching and learning process is a must in teaching young learners. Comic strip is one of the teaching materials that can be used for creating fun learning activities for young learners. In developing a digital comic strip, the English teacher should not have a good ability in drawing. They may use the application that is available in bitstrips.com to produce a digital comic strip without need to care about drawing pictures. Teaching English for young learners using a digital comic strip is recommended because it brings positive effect toward the learners' English language mastery. In addition, the use of digital comic strip could reduce the cost that the teachers need to provide a good teaching media.

arts approach. English Teaching: Practice and Critique, 93-112.

Brown, H. D. 2001. Teaching by Principles: An Interactive Approach to Language Pedagogy. New York: Pearson Education, Inc.

Cameron, L. 2005. Teaching Languages to Young Learners. Cambridge: Cambridge University Press. 
Choudhury, R. U. 2014. The Role of Culture in Teaching and Learning English as a Foreign Language. International Journal of Multi Disciplinary Research, 4 (1), 1-20.

Csabay, N. 2006. Using Comic Strips in Language Classes. English Teaching Forum No. 1, 24-26.

Dick, W., Carey, L., \& Carey, J. O. 2005. The Systematic Design of Instruction. Boston: Pearson.

Ellis, G., \& Brewster, J. 2014. The Storytelling Handbook for Primary ENglish Language Teachers. London: British Council.

Enright, D. S., \& McCloskey, M. L. 1998. Integrating English. Reading, MA: Newbury House Publisher.

Fairrington, B. 2009. Drawing Cartoon \& Comics for Dummies. Indiana: Wiley Publishing, Inc.

Graham, S. 2011. Comics in the Classroom: Something to be Taken Seriously. Language Education in Asia, 2 (1), 92-102.

Gunduz, N. 2005. Computer Assisted Language Learning. Journal of Language and Linguistics Studies, 193-214.

Halliwell, S. 1993. Teaching English in the Primary Classroom. Essex: Longman Group UK Limited.

Handayani, M. P. 2013. Using Chindren Short Stories to Enhance Students' Reading Comprehension. Journal of English and Education, 1 (1), 133-141.

Harmer, J. 2007. The Practice of English Language Teaching. Essex: Pearson Education Limited.

Karabacak, K., \& Erdem, S. 2015. The Effect of Using English Story Book in ENglish Courses by Adapting them to Different Activities on the Foreign Language Success of the Students. Procedia - Social and Behavioral Sciences 176, 1028-1033.

Kobayashi, H. 2011. Effects of Comic Strips on Reading Comprehension and Written Retelling. Sophia linguistica: working papers in linguistics, (59), 203-222.
Littlewood, W. 2001. Literature in the School Foreign-Language Course. In C. Brumfit, \& R. Carter, Literature and Language Teaching. Oxford: Oxford University Press.

Liu, J. 2004. Effects of Comic Strips on L2 Learners' Reading Comprehension. TESOL QUARTERLY, 38 (2), 225-243.

Megawati, F., \& Anugerahwati, M. 2012. Comis Strips: A Study on the Teaching of Writing Narrative Texts to Indonesian EFL Students. TEFLIN Journal, 23 (2), 183-205.

Merc, A. 2014. The Effect of Comic Strips on EFL Reading Comprehension. International Journal on New Trends in Education and its Implication 4 (1), 54-64.

Miangah, T. M., \& Nezarat, A. 2012. MobileAssisted Language Learning. International Journal of Distributed and Parallel System, 3 (1), 309-319.

Mixon, M. t., \& Temu, P. 2006. First Road to Learning Language through Stories. English Teaching Forum No. 2, 14-19.

Pardede, P. 2011. Using Short Stories to Teach Language Skills. Journal of ENglish Teaching, 1 (1), 14-27.

Pourkalhor, O., \& Kohan, N. 2013. Teaching Reading Comprehension through Short Stories in Advanced Classes. Asian Journal of Sciences \& Humanities, 52-60.

Rokhayani, A., \& Utari, A. R. 2014. The Use of Comic Strip as an English Teaching Media for Junior High School Students. Language Circle Journal of Language and Literature, 8 (2), 143-149.

Saka, F. Ö. 2014. Short Stories in English Language teaching. International Online Journal of Education and Teaching (IOJET), 1 (4), 278-288.

Scott, W. A., \& Yetreberg, L. H. 2000. Teaching English to Children. New York: Longman Group UK Ltd.

Violetta-Irene, K. 2015. The Use of Literature in the Language Classroom: Method and Aims. International Journal of Information and Education Technology, 5 (1), 74-79. 